\title{
LITERATURE REVIEW EFEKTIFITAS TERAPI RENDAM KAKI AIR HANGAT PADA PASIEN HIPERTENSI
}

\author{
Diana $^{1}$, Indah Puspitasari ${ }^{2}$ Rika Harini ${ }^{3 .}$ \\ ${ }^{1}$ Mahasiswa Program Studi Keperawatan D3, \\ Jurusan Keperawatan, Sekolah Tinggi Ilmu \\ Kesehatan Bani Saleh \\ Email: dianasmsdn@gmail.com \\ ${ }^{2}$ Program Studi Keperawatan D3, Jurusan \\ Keperawatan, Sekolah Tinggi Ilmu Kesehatan \\ Bani Saleh \\ Email: indah@stikesbanisaleh.ac.id \\ ${ }^{3}$ Program Studi Keperawatan S1, Jurusan \\ Keperawatan, Sekolah Tinggi Ilmu Kesehatan \\ Bani Saleh \\ Email : rika_suri@yahoo.com
}

\begin{abstract}
Basic Health Research 2018 states the prevalence of hypertension based on the results of measurements in the population aged $\geq 18$ years by $34.1 \%$. The highest was in South Kalimantan (44.1\%), while the lowest was in Papua (22.2\%) and West Java 39.1\%. West Java Province was ranked second in the highest number of hypertension sufferers from 34 provinces in Indonesia. One therapy that can overcome hypertension is warm water foot bath therapy. The review of this literature aims to determine the effectiveness of warm water foot bath therapy in hypertensive patients. The design in this scientific paper is a literature review search using an electronic database that is Google Scholar. Keywords used in the search are hypertension, warm water foot bath therapy, and blood pressure. The results found 5 articles from Google Scholar discuss the effect of soaking feet of warm water in hypertensive patients. The literature review results from the five articles show that warm water foot bath therapy can reduce blood pressure.
\end{abstract}

Key Words : Hypertension, Hydrotherapy and Blood pressure

\section{PENDAHULUAN}

Penyakit jantung atau pembuluh darah, termasuk hipertensi merupakan penyakit yang mematikan banyak penduduk di negara maju dan negara berkembang. Banyak orang tidak menyadari bahwa dirinya menderita hipertensi, hal ini disebabkan gejalanya yang tidak nyata dan pada stadium awal belum menimbulkan gangguan yang serius pada kesehatannya (Triyanto, 2014).

Riset Kesehatan Dasar 2018 menyatakan prevalensi hipertensi berdasarkan hasil pengukuran pada penduduk usia $\geq 18$ tahun sebesar $34,1 \%$. Tertinggi di Kalimantan Selatan (44,1\%), sedangkan terendah di Papua sebesar $(22,2 \%)$ dan di Jawa Barat sebanyak 39,1\%. Provinsi Jawa Barat menduduki peringkat ke 2 terbanyak jumlah penderita hipertensi dari 34 provinsi di Indonesia (Riskesdas, 2018).

Komplikasi serius yang di akibatkan oleh hipertensi membuat penderita merasa perlu untuk mencari alternatif 
menyelesaikan masalah baik secara farmakologi maupun nonfarmakologi. Terapi farmakologi yaitu dengan obatobatan dan terapi non farmakologi yang dapat dilakukan pada penderita hipertensi yaitu: Teknik relaksasi progresif, terapi musik, terapi diet, senam, yoga dan hidroterapi (rendam kaki air hangat) (Triyanto, 2014).

Rendam kaki air hangat adalah salah satu terapi non farmakologis yang mudah dan murah yang dapat digunakan untuk menurunkan tekanan darah pada penderita hipertensi. Selain untuk menurunkan tekanan darah, terapi rendam kaki ini bisa digunakan sebagai salah satu terapi yang memulihkan otot sendi yang kaku. Banyak metode yang dapat diterapkan dengan merendam kaki menggunakan air hangat (Wijayanti, 2009).

\section{METODE}

Metode dalam penulisan karya tulis ilmiah ini adalah menggunakan studi literature review. Studi literature review adalah uraian tentang teori, temuan dan bahan penelitian lain yang diperoleh dari bahan acuan untuk dijadikan landasan kegiatan penelitian untuk menyusun kerangka pemikiran yang jelas dari perumusan masalah yang ingin diteliti. Artikel yang digunakan pada literature review ini adalah artikel yang didapatkan dengan menggunakan 1 database Google Scholar dan dengan memasukan kata kunci artikel. Artikel yang digunakan adalah 5 artikel yang di terbitkan sepuluh tahun terakhir.

\section{HASIL DAN PEMBAHASAAN}

Berdasarkan penelitian Wulandari, et al. (2016) yang berjudul Pengaruh Rendam Kaki Menggunakan Air Hangat dengan Campuran Garam dan Serai Terhadap Penurunan Tekanan Darah Pada Penderita Hipertensi ini berpengaruh terhadap tekanan darah. Setelah diberikan intervensi tersebut menunjukan adanya penurunan tingkat hipertensi. Penderita hipertensi stadium III (tinggi) dan stadium II (sedang) untuk tekanan darah sisitolik sudah tidak ada, 17 responden mengalami penurunan tingkat hipertensi menjadi hipertensi stadium I (ringan) dan 69 responden menjadi normal. Untuk diastolik stadium II sudah tidak ada, 21 responden turun menjadi stadium 1 dan 65 responden menjadi normal.

Hal ini sejalan dengan penelitian Ferayanti et al. (2017) dengan pemberian terapi rendam kaki air hangat dan relaksasi nafas dalam ini berpengaruh terhadap tekanan darah. Setelah diberikan terapi rendam kaki air hangat dan relaksasi nafas dalam selama dua minggu dengan penurunan rata-rata sistolik sebesar 22,71 $\mathrm{mmHg}$ dan diastolik sebesar $5,45 \mathrm{mmHg}$. Dibuktikan juga oleh peneltian terbaru Malibel et al. (2020) yang berjudul Pengaruh Pemberian Hidroterapi (Rendam Kaki Air Hangat) Terhadap Penurunan Tekanan Darah Pada Pasien Hipertensi di Wilayah Kerja Puskesmas Sikumana Kota Kupang. Berdasarkan penelitian ini didapatkan hasil, sebelum dilakukan hidroterapi tekanan darah sistolik rata-rata adalah 140-159 mmHg, sedangkan tekanan darah diastolik yaitu 90-99 $\mathrm{mmHg}$ dan tekanan darah sesudah diberikan terapi rendam kaki air hangat terjadi penurunan tekanan darah sistolik yaitu <140 mmHg sebanyak 38 lansia, sdangkan pada tekanan darah diastolik terjadi penurunan yaitu $<90 \mathrm{mmHg}$ sebanyak 38 responden

Penelitian Hartinah et al. (2019) menyebutkan bahwa tekanan darah sistolik pada kelompok intervensi sebelum hidroterapi diberikan rata-rata 165,00 mmHg sedangkan tekanan darah diastolik rata-rata adalah $101,00 \mathrm{mmHg}$ dan setelah dilakukan hidroterapi adalah 151,00 $\mathrm{mmHg}$ tekanan darah sistolik sedangkan tekanan darah diastolik rata-rata adalah 92,00 $\mathrm{mmHg}$. Hal ini sesuai dengan teori bahwa rendam kaki air hangat dapat mendilatasi pembuluh darah, melancarkan peredaran darah, dan memicu syaraf yang ada pada 
telapak kaki untuk bekerja. Hangatnya air membuat sirkulasi darah menjadi lancar. (Lalage, 2015).

Jika dilihat dari segi waktu berdasarkan ke lima jurnal ini, Penelitian Hartinah et al. (2019) yang berjudul The Effect Of Hydrotherapy on Blood Pressure of Hypertensive Patients in Public Hospital of RA Kartini Jepara adalah yang efektif berdasarkan waktu yaitu membutuhkan waktu \pm 15 menit, 1 kali sehari selama 5 hari berturut-turut. Berbeda dengan penelitian empat lainnya rata rata membutuhkan waktu selama tujuh hari. Jika dilihat dari penurunan tekanan darah sistolik ataupun diastolik penelitian Malibel et al. (2020) adalah yang paling efektif berdasarkan penurunan sistolik dan diastolik karena dari hasil penelitian menunjukan penurunan tekanan darah sistolik rata-rata $10-39 \mathrm{mmHg}$ dan diastolik 20-28 mmHg.

Dalam literature review pada 5 jurnal ini yang membahas tentang pengaruh rendam kaki air hangat didapatkan hasil bahwa penderita hipertensi yang mendapatkan terapi rendam kaki air hangat ini efektif dalam menurunkan tekanan darah.

\section{KESIMPULAN}

Dari studi literature review penerapan terapi rendam kaki air hangat pada pasien hipertensi dapat ditarik kesimpulan bahwa terapi rendam kaki air hangat bermaanfaat untuk menurunkan tekanan darah, mengurangi stress dan memberikan ketenangan. Terapi rendam kaki air hangat dilakukan \pm 15 menit, 1 kali sehari selama 5 hari berturut-turut. Setelah terapi diberikan maka dilakukan pengukuran tekanan darah untuk mengevaluasi seberapa efektif terapi yang dilakukan.

\section{SARAN}

1. Bagi Profesi Keperawatan

Pada telaah literature review terapi rendam kaki air hangat sangat efektif dalam menurunkan tekanan darah sehingga diharapkan perawat dapat melakukan teknik rendam kaki air hangat untuk menurunkan tekanan darah.

2. Bagi Pendidikan Keperawatan

Bidang keperawatan komunitas dapat menjadikan hasil Karya Ilmiah literature review ini sebagai landasan untuk pengembangan ilmu keperawatan yang aplikatif terhadap pelaksanaan intrevensi kolaborasi dalam hal menurunkan hipertensi.

\section{REFERENSI}

Dewi. (2016). Pengaruh terapi rendam kaki air hangat terhadap perubahan tekanan darah pada penderita hipertensi di RT 7 RW 5 Kelurahan Wonoteto Kecamatan Wonokromo Surabaya. Jurnal Keperawatan. Vol: 5 No. 2.

Triyanto, Endang (2014). Pelayanan keperawatan bagi penderita hipertensi. Yogyakarta: GRAHA ILMU.

Ferayanti, et al. (2017). Efektifitas terapi rendam kaki air hangat dan relaksasi nafas dalam terhadap tekanan darah. Nurscope : Jurnal Keperawatan dan Pemikiran Ilmiah.

Hartinah, et al. (2019). The Effect Of Hydrotherapy on Blood Pressure of Hypertensive Patients in Public Hospital of RA Kartini Jepara. Advances in Health Sciences Research. Volume 15.

Lalage, Zerlina. (2015). Hidup sehat dengan terapi air. Yogyakarta: Abata Press.

Malibel, et al. (2020). Pengaruh pemberian hidroterapi (rendam kaki air hangat) terhadap penurunan tekanan darah pada pasien hipertensi di Wilayah Kerja Puskesmas Sikumana Kota Kupang. CHMK HEALTH JOURNAL. Vol 4 No 1.

Riset Kesehatan Dasar (Riskesdas) 2018. Hasil utama Riskesdas 2018. Jakarta: Badan Litbangkes, Kemenkes RI. 
Wijayanti D. (2009). Sehat dengan pengobatan alami. Yogyakarta :Venus.

Wulandari, Arifianto, \& Sekarningrum, D. (2016). Pengaruh rendam kaki menggunakan air hangat dengan campuran garam dan serai terhadap penurunan tekanan darah pada penderita hipertensi di Wilayah Podorejo RW 8 Ngaliyan. Jurnal keperawatan. Vol 7, No 1 (2016). 